\title{
Dopamine $\boldsymbol{\beta}$-Hydroxylase of Bovine Adrenal Medullae
}

\author{
A RAPID PURIFICATION PROCEDURE
}

\author{
By A. FOLDES, P. L. JEFFREY, B. N. PRESTON and L. AUSTIN \\ Department of Biochemistry, Monash University, Clayton, Vic. 3168, Australia
}

(Received 7 October 1971)

\begin{abstract}
1. A rapid purification procedure for dopamine $\beta$-hydroxylase from bovine adrenalmedulla chromaffin granules is presented. The homogeneity of the purified enzyme was demonstrated by means of three independent criteria. The specific activity of the enzyme compares favourably with that obtained by more involved procedures. 2 . The stability of the enzyme was investigated and storage in polypropylene tubes was found preferable to storage in glass. 3. The soluble and particulate forms of dopamine $\beta$-hydroxylase appear to be identical, since membrane-bound and membrane-enclosed forms of the enzyme exhibit similar properties as regards size, charge and amino acid composition. 4. $\mathrm{Ca}^{2+}$ was found to stimulate the release of dopamine $\beta$-hydroxylase from bovine chromaffin granules in vitro. 5. An endogenous inhibitor of the enzyme was found in the chromaffin granules. This inhibitor was not inactivated either by heating at $100^{\circ} \mathrm{C}$ or by pretreatment with $p$-chloromercuribenzoate or $\mathrm{Cu}^{2+}$ ions.
\end{abstract}

Dopamine $\beta$-hydroxylase [3,4-dihydroxyphenethylamine, ascorbate- $\mathrm{O}_{2}$ oxidoreductase (hydroxylating), EC 1.14.2.1], the final enzyme in the biosynthesis of noradrenaline in sympathetically innervated tissues, was first purified from bovine adrenal glands in 1960 (Levin et al., 1960). Since then, several modifications of the original purification procedure have been published (Friedman \& Kaufman, 1965; Goldstein et al., 1965). The enzyme has been shown to be a copper protein requiring ascorbate for activity, and a two-step reaction sequence was proposed (Friedman \& Kaufman, 1965). The enzyme has been localized in granulated vesicles in both sympathetic-nerve terminals and adrenal-medulla chromaffin cells (Kirshner, 1962).

It has been reported (Belpaire \& Laduron, 1968; Winkler et al., 1970) that hypo-osmotic lysis of the chromaffin granules releases only about $50 \%$ of their total enzyme content, and the so-called particulate dopamine $\beta$-hydroxylase has been used as a marker for isolated chromaffin-granule membrane preparations (Viveros et al., 1969a). It has been confirmed in vivo (Viveros et al., 1969b) that two pools of dopamine $\beta$-hydroxylase activity exist in the adrenal granules, one pool being more readily released than the other on stimulation of the nerve.

The two forms of the enzyme that can be distinguished in vitro by hypo-osmotic and detergent lysis have been termed 'soluble' and 'particulate' respectively. In view of their origin within a subcellular component, the terms 'membrane-enclosed' and 'membrane-bound' are more appropriate.

Many investigators have studied the release of catecholamines and total protein from adrenal- medulla chromaffin granules in vitro (see, e.g., Poisner $\&$ Trifaro, 1967). However, very little reference has been made to the release of dopamine $\beta$-hydroxylase activity from the granule preparation in vitro, even though it is known from experiments in vivo (Viveros et al., 1968) that release of catecholamines from both the adrenal medulla and sympathetic nerves is accompanied by release of dopamine $\beta$-hydroxylase.

In the presence of endogenous inhibitors, dopamine $\beta$-hydroxylase can become the rate-limiting enzyme of the biosynthesis of noradrenaline (Creveling et al., 1962). The purification and characterization of such an inhibitor from bovine heart has been investigated in our laboratory (Austin et al., 1967; Chubb et al., 1969). This inhibitor appears stable to heating at $100^{\circ} \mathrm{C}$ in the crude state, and to be inactivated in vitro by prior incubation of the enzyme and inhibitor with $\mathrm{Cu}^{2+}$ ions before addition of substrate, but not with thiol-reactive reagents such as $p$-chloromercuribenzoate or $N$-ethylmaleimide. For such an inhibitor to have any physiological significance, it must be present at the site of action of dopamine $\beta$-hydroxylase. This means that in the adrenal medulla, the inhibitor must be present in the chromaffin granules themselves. Belpaire \& Laduron (1970) and also Duch et al. (1968) have found an inhibitor in the soluble fraction of the adrenal medulla.

In the present paper a rapid purification procedure for dopamine $\beta$-hydroxylase is presented, and the two forms of the enzyme in the chromaffin granules, the release of the enzyme protein from the granules and the existence of an endogenous inhibitor in the granules are investigated by using this preparation. 


\section{Experimental}

\section{Materials}

$\left[{ }^{3} \mathrm{H}\right] \mathrm{T}$ yramine (uniformly labelled, $10 \mathrm{mCi} / \mu \mathrm{mol}$ ) was obtained from New England Nuclear Corp., Boston, Mass., U.S.A. Catalase (39000 Sigma units/ $\mathrm{mg}$ ) was purchased from C. F. Boehringer und Soehne G.m.b.H., Mannheim, Germany. Triton $\mathrm{X}-100$ was a gift of Robert Bryce and Co., Melbourne, Australia:

DE-11 DEAE-cellulose powder was purchased from W. and R. Balston Ltd., Maidstone, Kent, U.K., and was washed with $1.0 \mathrm{M}-\mathrm{HCl}$, and then with water until the effluent was neutral. The cellulose powder was then washed with $1.0 \mathrm{M}-\mathrm{NaOH}$, water and the elution buffer before use.

Sephadex G-200 and G-100 were obtained from Pharmacia, Uppsala, Sweden, and were swollen, de-fined, degassed and equilibrated with degassed elution buffer before use.

Blue Dextran was purchased from Pharmacia, and $N$ - tris(hydroxymethyl)methyl - 2 - aminoethanesulphonic acid (TES) buffer was obtained from Sigma Chemical Co., St. Louis, Mo., U.S.A.

All other reagents were of analytical grade. Water used in the experiments was glass-distilled, and, where required, deionized.

\section{Methods}

Preparation of chromaffin granules. After we had found several purification methods for dopamine $\beta$-hydroxylase (Friedman \& Kaufman, 1965; Goldstein et al., 1965) unsuitable either because of the length of the purification procedure or because of the heterogeneity of the final product, a method of purification based on the chromaffin-granule preparation of Smith \& Winkler (1967) was developed. A similar preparation has been used by Smith \& Kirshner (1967) for the purification of other chromaffin-granule proteins from bovine and sheep adrenals.

Fresh bovine adrenal glands were defatted and packed in ice until arrival in the laboratory. The adrenal medullae were rapidly dissected free of cortical tissue, weighed and homogenized at $4^{\circ} \mathrm{C}$ in 4-5 vol. of cold iso-osmotic sucrose $(0.32 \mathrm{M})$ in a Servall Omnimix homogenizer, operated at $1000 \mathrm{rev}$./ min for $30 \mathrm{~s}$. All of the following steps were carried out at $4^{\circ} \mathrm{C}$. The homogenate was centrifuged at $1000 \mathrm{~g}$ for $15 \mathrm{~min}$ in an International model PR-2 centrifuge and the supernatant filtered through cheesecloth. Occasionally, the centrifuged pellet was rehomogenized and re-centrifuged as before and the filtered supernatants were combined. A crude mitochondrial fraction was sedimented at $10000 \mathrm{~g}$ for $30 \mathrm{~min}$ in a Sorvall RC-2B centrifuge. The centrifuge tubes were wiped clear of lipid, and the sediment was resuspended in ice-cold iso-osmotic sucrose, care being taken to avoid resuspending the erythrocyte layer beneath the mitochondrial pellet. A $10 \mathrm{ml}$ sample of this suspension was then layered on $30 \mathrm{ml}$ of icecold $1.6 \mathrm{M}$-sucrose and centrifuged at $100000 \mathrm{~g}$ for $60 \mathrm{~min}$ in an MSE Superspeed 65 ultracentrifuge. Best yields of chromaffin granules were obtained when the mitochondrial suspension contained the sediment from not more than $2 \mathrm{~g}$ of original medulla/ml of iso-osmotic sucrose. After the final centrifugation the chromaffin granules were obtained as a pink sediment at the bottom of the centrifuge tubes, most of the mitochondrial and other contaminating organelles being retarded at the interface between the $0.32 \mathrm{M}$ and $1.6 \mathrm{M}$-sucrose layers. The sediment containing the chromaffin granules was washed by gentle agitation in a small volume of cold $1.6 \mathrm{M}$-sucrose, which was then decanted to remove a small amount of light-brown contaminating protein occasionally found overlying the pink sediment.

The granules were resuspended in $10 \mathrm{~mm}$-potassium phosphate buffer, $\mathrm{pH} 7.2$, by using $1 \mathrm{ml}$ of buffer for the granules obtained from $10 \mathrm{~g}$ of original medulla.

Preparation of 'membrane-bound' and 'membraneenclosed' forms of the enzyme. Chromaffin granules were prepared as described above, and lysed three times in the absence of detergent. The combined supernatants were termed the 'hypotonic lysate', and this corresponds to the membrane-enclosed form. The final centrifuged pellet after the three washes was again resuspended in the $10 \mathrm{~mm}$-phosphate buffer and lysed in the presence of $0.1 \%(\mathrm{v} / \mathrm{v})$ Triton X-100 detergent. The supernatant after a centrifugation at $10000 \mathrm{~g}$ for $10 \mathrm{~min}$ was termed the 'Triton lysate', and this corresponds to the membrane-bound form.

Release of dopamine $\beta$-hydroxylase from chromaffin granules in vitro. For these experiments, chromaffin granules were prepared as described above, resuspended and washed three times in iso-osmotic sucrose, once in iso-osmotic $\mathrm{KCl}-\mathrm{NaCl}$-TES buffer (Poisner \& Trifaro, 1967) and samples $(0.2-0.5 \mathrm{ml})$ were incubated at $37^{\circ} \mathrm{C}$ in $2 \mathrm{ml}$ of iso-osmotic buffer containing the various substances specified in Table 2 . After 15-60 min, the incubation was stopped by addition of ice-cold sucrose, the granules were removed by centrifugation at $10000 \mathrm{~g}$ for $10 \mathrm{~min}$ and portions of the supernatant were assayed for catecholamines, total protein and dopamine $\beta$-hydroxylase activity.

Purification of dopamine $\beta$-hydroxylase. The chromaffin-granule preparation isolated as described above was usually frozen, three to five such preparations being pooled before the next step was commenced.

The granule suspension was thawed and a $10 \%$ $(\mathrm{v} / \mathrm{v})$ Triton $\mathrm{X}-100$ solution was added, to a final concentration of $0.1 \%$. The suspension was then stirred at $4^{\circ} \mathrm{C}$ for $45 \mathrm{~min}$, centrifuged at $1100 \mathrm{~g}$ for 
$10 \mathrm{~min}$ (Servall centrifuge) and the supernatant stored in ice. The sediment was resuspended in a small volume of $10 \mathrm{~mm}$-phosphate buffer and treated with Triton X-100 once more. The combined supernatants were centrifuged at $100000 \mathrm{~g}$ for $10 \mathrm{~min}$ (Superspeed 65 centrifuge) and the supernatant was dialysed against three or four $1 \mathrm{~h}$ changes of $50 \mathrm{vol}$. of 10mM-phosphate buffer, pH7.2, containing $10 \mu \mathrm{M}-\mathrm{CuSO}_{4}$.

When aqueous lysis only was required, the above procedure was followed with the omission of the Triton X-100 detergent.

DEAE-cellulose chromatography. The dialysis residue was tested for activity and adsorbed on a DEAE-cellulose column previously equilibrated with $10 \mathrm{~mm}$-phosphate buffer, pH7.2. The size of the column was $40 \mathrm{~cm} \times 1.8 \mathrm{~cm}$, although occasionally a $50 \mathrm{~cm} \times 2.5 \mathrm{~cm}$ column was used with larger amounts of protein. The non-adsorbed protein was eluted with $10 \mathrm{~mm}$-phosphate buffer and the adsorbed proteins were eluted with a linear salt concentration gradient $(0-0.8 \mathrm{M}-\mathrm{NaCl}$ in $10 \mathrm{~mm}$-phosphate buffer, pH 7.2). The fractions were assayed for enzyme activity and the active peak was pooled and concentrated by positive-pressure dialysis on a Diaflo ultrafilter (Amicon Corp., Lexington, Mass., U.S.A.).

Sephadex G-200 chromatography. The solution containing the enzyme (less than $4 \mathrm{ml}$ ) was applied to a column of Sephadex G-200 $(40 \mathrm{~cm} \times 1.8 \mathrm{~cm})$ previously equilibrated with $10 \mathrm{~mm}$-phosphate buffer containing $0.1 \mathrm{M}-\mathrm{NaCl}, \mathrm{pH} 7.2$. Occasionally, a larger $(50 \mathrm{~cm} \times 2.5 \mathrm{~cm})$ column was used, with comparable results. The void volume of the column was determined by using Blue Dextran. The protein was eluted with the $10 \mathrm{~mm}$-phosphate buffer containing $0.1 \mathrm{M}$ $\mathrm{NaCl}, \mathrm{pH}$ 7.2. The fractions containing activity were pooled and concentrated as described above.

Preparation of crude dopamine $\beta$-hydroxylase inhibitor from chromaffin granules. To establish the presence of an inhibitor in the chromaffin granules and to study some of its properties, the initial steps of the preparation of the inhibitor from heart (Chubb et al., 1969) were carried out on an aqueous chromaffin-granule lysate. Bovine adrenal-medulla chromaffin granules were prepared as described above, washed twice with $1.6 \mathrm{M}$-sucrose, and lysed twice in the phosphate buffer in the absence of detergent. The combined lysates were centrifuged at $10000 \mathrm{~g}$ for 10 min (Servall centrifuge) and the supernatant was boiled for $5 \mathrm{~min}$. The denatured proteins were removed by a further centrifugation $(1000 \mathrm{~g}, 15 \mathrm{~min})$ to yield a supernatant containing the crude inhibitor.

\section{Analytical methods}

Gel electrophoresis. To establish the homogeneity of the enzyme protein by polyacrylamide-gel electrophoresis, the method of Cain \& Pitney (1968) was used. The electrophoresis was run at $\mathrm{pH} 8.3$ at a constant current of $2 \mathrm{~mA} / \mathrm{gel}$ at $4^{\circ} \mathrm{C}$ and the protein bands were stained with $0.5 \%(\mathrm{w} / \mathrm{v})$ Amido Black dye in $7 \%(\mathrm{v} / \mathrm{v})$ acetic acid.

Protein assay. Protein was assayed by the method of Lowry et al. (1951), with dried bovine serum albumin as standard.

Catecholamine assay. Catecholamines were assayed by the trihydroxyindole procedure of Crout (1961).

Copper assay. Copper was assayed by a modification of the method of Felsenfeld (1960).

Thin-layer chromatography. Samples were prepared for t.l.c. to detect the presence of lipids as follows. Samples of purified enzyme were freeze-dried and the residue was taken up in a small volume of chloroform-methanol $(1: 1, \mathrm{v} / \mathrm{v})$ and centrifuged at $1500 \mathrm{~g}$ for $10 \mathrm{~min}$; the supernatant was removed by aspiration, and the sediment washed twice with small volumes of chloroform. The combined washings were concentrated under $\mathrm{N}_{2}$ and chromatographed. Chromatography was on Merck F254 Kieselgel thinlayer medium previously washed with hexane-ether $(7: 3, v / v)$. After spotting of the samples at the origin, ascending chromatography was carried out with a polar solvent, chloroform-methanol-acetoneacetic acid-water (10:2:4:2:1, by vol.). When the solvent front had reached a position approximately half-way up the plate, the plate was removed and dried. Further chromatography was carried out in the same direction in a non-polar solvent, hexaneether-water $(75: 25: 3$, by vol.) until the solvent approached the upper edge of the plate. The plate was then dried and sprayed with $3 \mathrm{M}-\mathrm{H}_{2} \mathrm{SO}_{4}$, lipid spots were developed by heating the plate at $80^{\circ} \mathrm{C}$, detected by u.v. light and identified by comparison with standards treated in an identical manner.

Assay of dopamine $\beta$-hydroxylase activity and inhibitory activity. Enzymic activity was assayed by a modification of the method of Friedman \& Kaufman (1965), based on the conversion of uniformly labelled $\left[{ }^{3} \mathrm{H}\right]$ tyramine into octopamine. The incubation mixture contained, in a total volume of $113 \mu \mathrm{l}$ : potassium phosphate buffer, $\mathrm{pH} 6.5,10 \mu \mathrm{mol}$; fumarate, $\mathrm{pH} 6.5$, $5 \mu \mathrm{mol}$; iproniazid phosphate, $\mathrm{pH} 6.5,0.125 \mu \mathrm{mol}$; catalase, 780 Sigma units; ascorbate, $0.5 \mu \mathrm{mol}$; tyramine, $1.0 \mu \mathrm{mol}(0.1 \mu \mathrm{Ci})$; and sufficient enzyme to yield a high activity.

When inhibitory activity was assayed, the enzyme and inhibitor were preincubated at $37^{\circ} \mathrm{C}$ for $30 \mathrm{~min}$ before the addition of the incubation mixture and substrate (I. W. Chubb, personal communication).

Incubation was carried out, after the addition of substrate, for $30 \mathrm{~min}$ at $37^{\circ} \mathrm{C}$. The reaction was stopped by the addition of freshly titrated $4.0 \mathrm{M}-\mathrm{NH}_{3}$ $(200 \mu \mathrm{mol})$, and the octopamine formed was oxidized to $p$-hydroxybenzaldehyde by the addition of periodate $(2.28 \mathrm{mmol})$, for exactly $4 \mathrm{~min}$. The oxidation was stopped by the addition of $\mathrm{NaHSO}_{3}(1.53 \mathrm{mmol})$, 
the reaction mixture acidified with $\mathrm{HCl}(152 \mu \mathrm{mol})$, and the labelled $p$-hydroxybenzaldehyde was then extracted into toluene and its radioactivity counted by liquid scintillation in a Picker Liquimat 220 Liquid-Scintillation Spectrophotometer (Picker Nuclear, White Plains, N.Y., U.S.A.). The efficiency of the counter for ${ }^{3} \mathrm{H}$ in toluene in this system was $31 \%$.

\section{Physical methods}

Sedimentation velocity. This measurement was performed in a Beckman Spinco model E ultracentrifuge equipped with schlieren optics at $50740 \mathrm{rev} . / \mathrm{min}$ at $5^{\circ} \mathrm{C}$ in a cell with a $30 \mathrm{~mm}$ centre- piece. Protein concentration was $2 \mathrm{mg} / \mathrm{ml}$ and the buffer used was $10 \mathrm{~mm}$-phosphate, $\mathrm{pH} 7.2$, containing $0.1 \mathrm{M}-\mathrm{NaCl}$.

Sedimentation-equilibrium ultracentrifugation. Molecular weights were determined by sedimentation-equilibrium ultracentrifugation by the method of Yphantis (1964) in a Beckman Spinco model E ultracentrifuge. Rotor speed was $12590 \mathrm{rev} . / \mathrm{min}$ and the duration of the run was $24 \mathrm{~h}$ at a protein concentration of $300 \mu \mathrm{g} / \mathrm{ml}$.

\section{Results}

The convenience of this method for the purification of dopamine $\beta$-hydroxylase lies partly in the initial

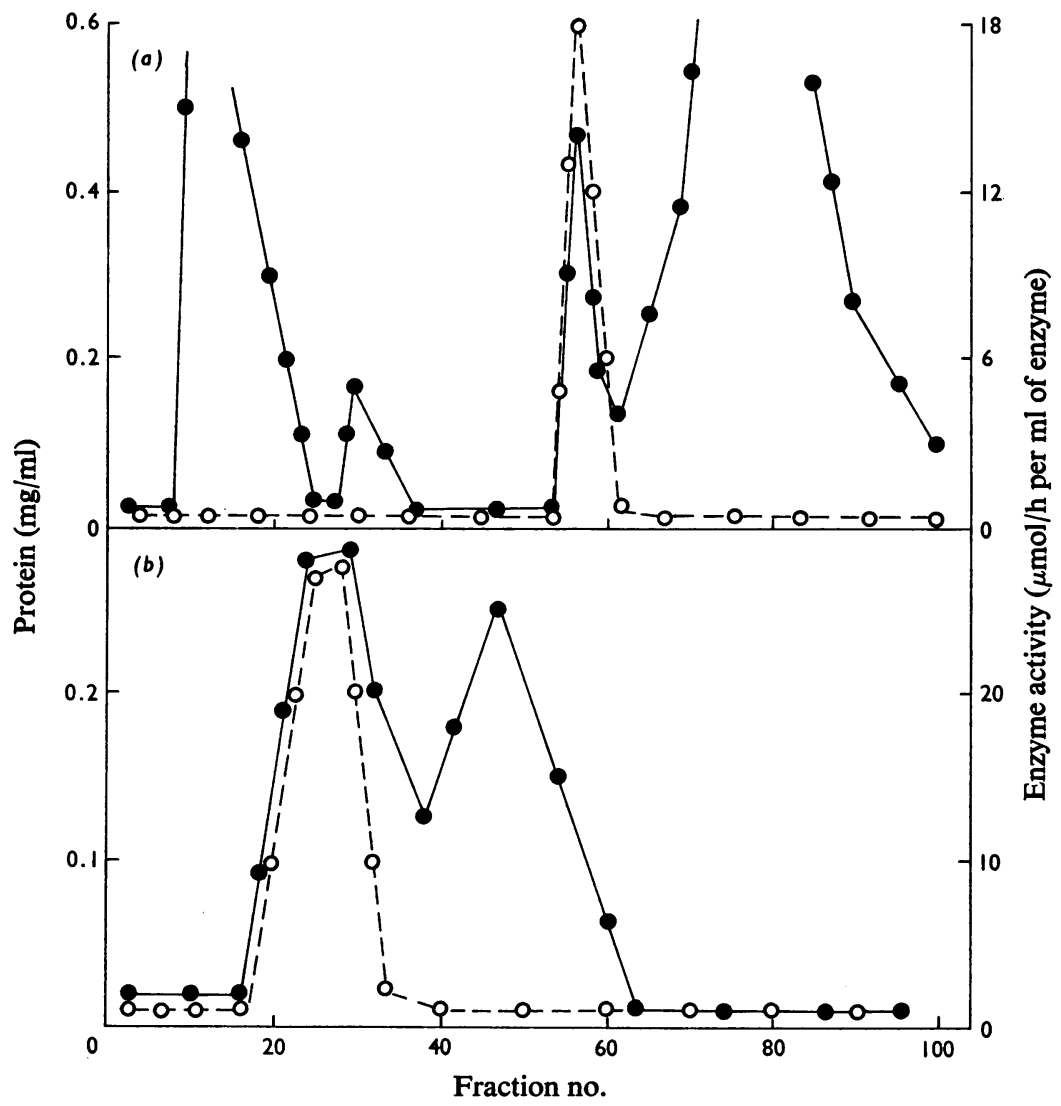

Fig. 1. Chromatography of dopamine $\beta$-hydroxylase

(a) DEAE-cellulose elution pattern. Column size was $40 \mathrm{~cm} \times 1.8 \mathrm{~cm}$, flow rate was $0.8 \mathrm{ml} / \mathrm{min}$ and fraction size was $10 \mathrm{ml}$. A linear salt gradient from 0 to $0.8 \mathrm{M}-\mathrm{NaCl}$ in $10 \mathrm{~mm}$-phosphate buffer, $\mathrm{pH} 7.2$, of $800 \mathrm{ml}$ total volume, was applied at fraction 42 . (b) Sephadex G-200 elution pattern. Column size was $40 \mathrm{~cm} \times 1.8 \mathrm{~cm}$; the void volume as measured by Blue Dextran was $33 \mathrm{ml}$. The elution buffer was $10 \mathrm{~mm}$-phosphate, $\mathrm{pH} 7.2$, containing $0.1 \mathrm{M}-\mathrm{NaCl}$. Flow rate was $0.25 \mathrm{ml} / \mathrm{min}$ under a pressure-head of $68 \mathrm{~cm}$. Fraction size was $2.0 \mathrm{ml}$. Enzymic activity ( $(0)$ was assayed as described in the Experimental section. Protein $(\bullet)$ was determined by the method of Lowry et al. (1951). 


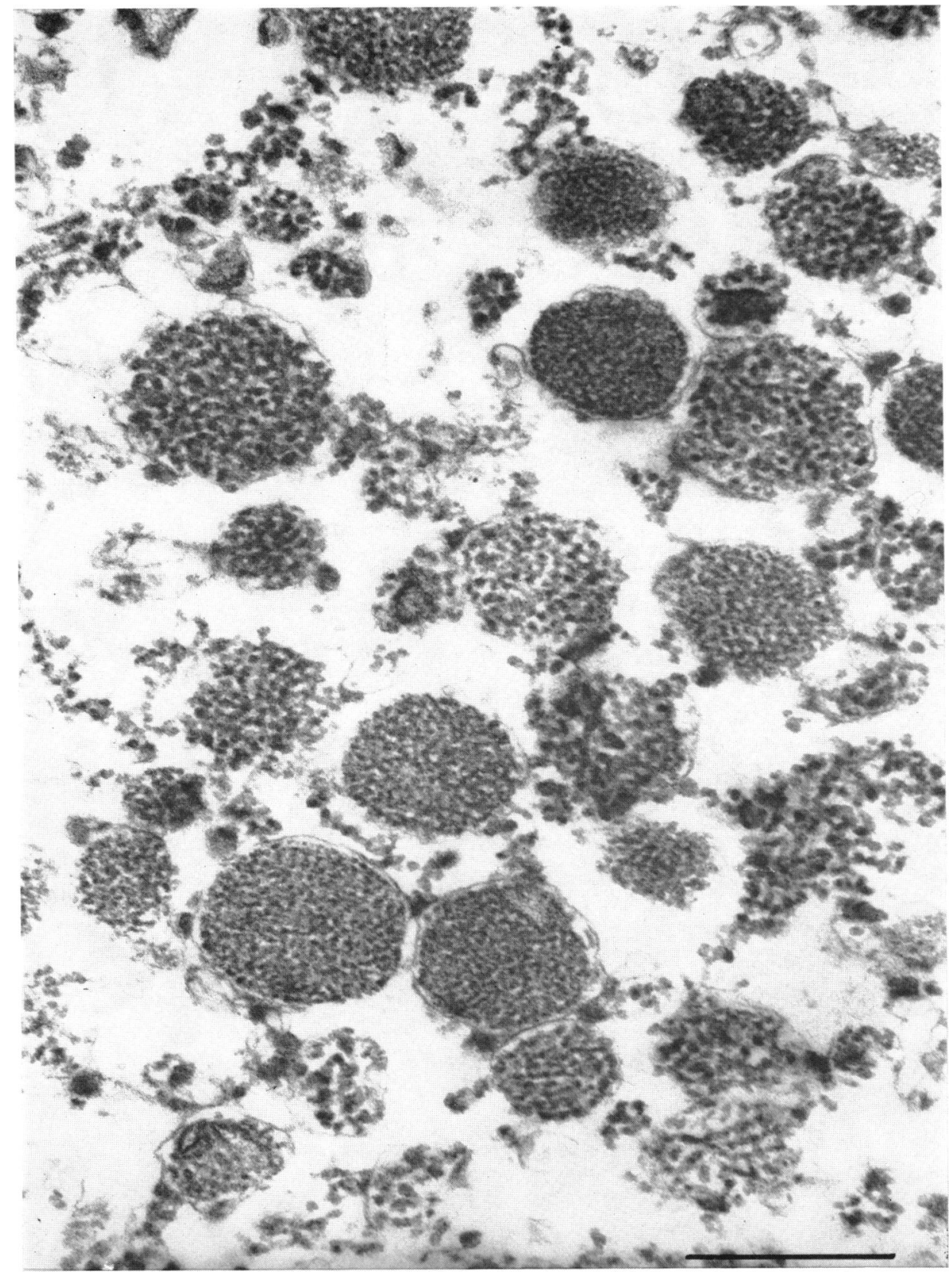

EXPLANATION OF PLATE I

Electron micrograph of purified bovine adrenal-medulla chromaffin granules. The granules were isolated as described in the Experimental section, fixed in 1\% osmium tetroxide buffered at pH7.2 with Sorensen's phosphate buffer containing $0.32 \mathrm{M}$-sucrose, embedded in Araldite, stained with saturated uranyl acetate in $50 \%(\mathrm{v} / \mathrm{v})$ methanol followed by Reynolds lead citrate, and observed in a Hitachi HU 11A electron microscope. The bar represents $0.5 \mu \mathrm{m}$ at a magnification of 52500 . 
isolation of chromaffin granules from the adrenal medulla. The granules are isolated free of mitochondrial contamination and their homogeneity is shown in Plate 1.

The elution of solubilized proteins from the medullary granules from DEAE-cellulose is shown in Fig. 1(a). The enzyme was eluted as a single protein peak at a salt concentration of $0.16-0.18 \mathrm{M}$.

Further purification was achieved by gel chromatography. The enzyme activity was associated with a protein eluted just after the void volume, as shown in Fig. 1(b).

Polyacrylamide-gel electrophoresis of this active fraction yielded one slow-moving band, which corresponds in position to the reported mobility of dopamine $\beta$-hydroxylase (Gibb et al., 1967). Occasionally, however, the preparation contained a small amount of chromogranin A contamination, as also shown by sedimentation-velocity ultracentrifugation. Chromogranin A is a soluble chromaffin-granule protein which is eluted from Sephadex G-200 just after dopamine $\beta$-hydroxylase. In this case, the two proteins could be separated on a column of Sephadex G-200 $(20 \mathrm{~cm} \times 1 \mathrm{~cm})$. The enzyme preparation thus obtained had a constant specific activity across the protein peak and after concentration yielded a single band on polyacrylamide-gel electrophoresis. Attempts to recover activity from the gels have proved unsuccessful, possibly owing to removal of the enzyme-bound copper by the applied current, or to $\mathrm{pH}$-inactivation at the gel $\mathrm{pH}(8.9)$.

Sedimentation-velocity ultracentrifugation of the purified enzyme showed a single, symmetrical peak sedimenting with $s_{20} 10.24 \pm 0.12 \mathrm{~S}$.

Rate-zonal ultracentrifugation on a linear sucrose density gradient showed a single protein peak with associated catalytic activity. When compared with other proteins of known sedimentation coefficient (Martin \& Ames, 1961), the protein peak had an $s$ value of approx. 10S (Fig. 2).

Table 1 shows a comparison of the purification of dopamine $\beta$-hydroxylase by the method reported in

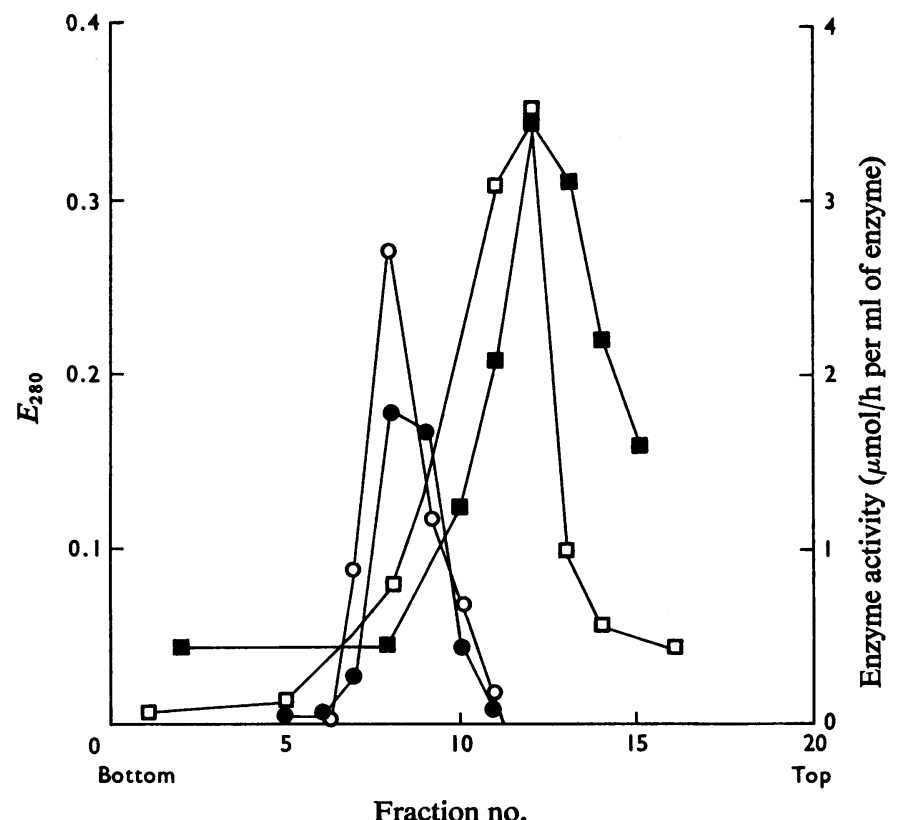

Fig. 2. Sucrose-density-gradient centrifugation

Samples $(0.2 \mathrm{ml})$ of haemoglobin $(\square), \gamma$-globulin $(\square)$ and purified dopamine $\beta$-hydroxylase ( $\bullet$ ), each containing $0.36 \mathrm{mg}$ of protein, were centrifuged at $75000 \mathrm{~g}$ on linear density gradients containing $5-20 \%$ sucrose in $10 \mathrm{~mm}-$ phosphate buffer, $\mathrm{pH} 7.2$, for $15.25 \mathrm{~h}$ in a Spinco model $\mathrm{L}$ preparative ultracentrifuge. The linearity of the gradient was shown by using Bromophenol Blue dye. Fractions (5 drops) were collected through a fine syringe needle inserted into the bottom of the centrifuge tubes, the $E_{280}$ of the fractions was measured as an indication of protein concentration, and each fraction was assayed for dopamine $\beta$-hydroxylase activity (o) by the procedure described in the Experimental section. 


\section{Table 1. Purification of dopamine $\beta$-hydroxylase}

(a) Method used in present paper. A $622.5 \mathrm{~g}$ (wet wt.) sample of bovine adrenal medullae was processed. Enzymic activity, expressed as $\mu \mathrm{mol}$ of product formed/h, was assayed as described in the Experimental section.

$\begin{array}{lccc}\text { Purification step } & \begin{array}{c}\text { Total activity } \\ (\mu \mathrm{mol} / \mathrm{h})\end{array} & \begin{array}{c}\text { Total protein } \\ (\mathrm{mg})\end{array} & \begin{array}{c}\text { Specific activity } \\ (\mu \mathrm{mol} / \mathrm{h} \text { per mg of protein) }\end{array} \\ \text { Homogenate } & 2762.6 & 50644.0 & 0.054 \\ \text { 1000g supernatant } & 2453.2 & 28286.0 & 0.086 \\ \text { Lysed granules } & 1125.0 & 915.0 & 1.23 \\ \text { DEAE-cellulose } & 540.0 & 16.9 & 32.0 \\ \text { Sephadex G-200 } & 483.0 & 4.6 & 104.5\end{array}$

(b) Method of Friedman \& Kaufman (1965). A $6500 \mathrm{~g}$ (wet wt.) sample of whole bovine adrenals was processed.

$\begin{array}{lccc}\text { Purification step } & \begin{array}{c}\text { Total activity } \\ (\mu \mathrm{mol} / \mathrm{h})\end{array} & \begin{array}{c}\text { Total protein } \\ (\mathrm{mg})\end{array} & \begin{array}{c}\text { Specific activity } \\ (\mu \mathrm{mol} / \mathrm{h} \text { per mg of protein })\end{array} \\ \text { Microsomal fraction } & 49300 & 167000 & 0.30 \\ \text { After } 44000 \mathrm{~g} \text { centrifugation } & 38000 & 154000 & 0.25 \\ \text { After }\left(\mathrm{NH}_{4}\right)_{2} \mathrm{SO}_{4} \text { pptn. } & 48300 & 167000 & 0.29 \\ \text { After charcoal treatment } & 43400 & 106000 & 0.41 \\ \text { After ethanol fractionation } & 11000 & 8000 & 1.38 \\ \text { DEAE-cellulose } & 2265 & 305 & 7.50 \\ \text { Sephadex G-200 } & 1170 & 12.5 & 93.6\end{array}$

this paper and that of Friedman \& Kaufman (1965). Although the final specific activities of the two preparations are comparable, the yield of pure enzyme/g of original medulla is approximately four times as much by this rapid method, assuming that approx. $50 \%$ of the mass of the defatted adrenal gland is medullary tissue.

\section{Stability}

The enzyme preparation at any stage before the DEAE-cellulose chromatography was proved to be stable when frozen at $-20^{\circ} \mathrm{C}$ for several weeks. However, the purified enzyme, when stored in $50 \mu 1$ fractions at $-20^{\circ} \mathrm{C}$, was found to lose $50 \%$ of its activity in 6 days and $90 \%$ in 28 days. The addition of bovine serum albumin, to a final protein concentration of $5 \mathrm{mg} / \mathrm{ml}$, only decreased the loss of activity of the stored samples by about $10 \%$ after 21 days. The addition of ascorbate, the primary substrate, had no effect on the stability of the enzyme. Storage at $-70^{\circ} \mathrm{C}$ or as an ammonium sulphate suspension at $4^{\circ} \mathrm{C}$ led to no appreciable improvement in stability. Friedman \& Kaufman (1965) found the enzyme stable in ammonium sulphate, but storage in this form was found unsuitable for daily use.

Subsequently it was found that activity was retained for a longer period when the enzyme was stored frozen in large batches, of the order of $5-10 \mathrm{ml}$. This finding led to the suggestion that enzyme-bound copper may be removed by adsorption on the glass of the storage container. When stored in large samples, less of the total enzyme would presumably be involved in such interactions. To test this hypothesis a $5 \mathrm{ml}$ sample of enzyme was stored in a capped polypropylene tube in ice, to avoid any denaturation by freezing and thawing. Enzyme kept in this manner showed no measurable loss of activity in 21 days. There is also some indication that storage in polypropylene tubes even at $-20^{\circ} \mathrm{C}$ results in a reasonable improvement in stability over storage in glass.

\section{Membrane-bound and membrane-enclosed enzyme}

The two forms of the enzyme, corresponding to 'Triton lysate' and 'hypotonic lysate' respectively were prepared as described in the Experimental section. The 'hypotonic lysate' had $66 \%$ of the total dopamine $\beta$-hydroxylase activity. The two preparations behaved identically on DEAE-cellulose chromatography in that activity was eluted as a single peak at the same $\mathrm{NaCl}$ concentration in both cases. The concentration of added copper required for $50 \%$ inhibition of the enzyme was $0.2 \mathrm{~mm}$ for both preparations. The two preparations also yielded bands in corresponding positions on polyacrylamide-gel electrophoresis, and, on gel chromatography, activity was eluted just after the void volume of the respective columns. The weight-average molecular weights of the two preparations at the post-Sephadex stage were found comparable by sedimentation-equilibrium ultracentrifugation.

An analysis of the two purified preparations shows that they have a very similar amino acid composition. 


\section{Release of 'soluble' chromaffin-granule components in vitro}

The effects of various combinations of substances on the release of protein, catecholamines and dopamine $\beta$-hydroxylase from the chromaffin granules in vitro is shown in Table 2 . It is evident that $\mathrm{Mg}^{2+}$ in the presence of ATP is most effective in the release of total protein and catecholamines. However, the release of dopamine $\beta$-hydroxylase seems to be stimulated by $\mathrm{Ca}^{2+}$ ions in the presence of ATP, $\mathrm{Mg}^{2+}$ having little or no comparable effect. In some experiments $\mathrm{Ca}^{2+}$ alone, in the absence of added ATP, also caused a $20-30 \%$ increase in dopamine $\beta$ hydroxylase release. This probably reflects the amount of endogenous ATP in the various granule preparations.

This specific effect of $\mathrm{Ca}^{2+}$ was also observed on the release of dopamine $\beta$-hydroxylase from a crude mitochondrial fraction, and has shown itself reproducible in at least five experiments performed on different purified granule preparations.

\section{Endogenous inhibitor in chromaffin granules}

Table 3 demonstrates the presence of an endogenous inhibitor of dopamine $\beta$-hydroxylase in the boiled supernatant fraction of bovine adrenalmedulla chromaffin granules, and also that the inhibition was not reversed by prior incubation of the inhibitor with either $0.1 \mathrm{~mm}$-p-chloromercuribenzoate or $\mathrm{Cu}^{2+}$ at $10-100 \mu \mathrm{M}$ final concentration. Therefore the inhibitor differs from both the inhibitor isolated from bovine heart (Chubb et al., 1969) and that found in adrenal medulla (Duch et al., 1968; Belpaire \& Laduron, 1970). The observed inhibition by added copper at high concentration is a characteristic of copper-containing enzymes.

\section{Discussion}

Because of its brevity (approx. 4 days from starting material to homogeneous pure enzyme) and its reproducibility (in 24 independent preparations) the method of purification of dopamine $\beta$-hydroxylase presented here is more convenient than other published methods. Significant loss of total activity at the ammonium sulphate and ethanol fractionations and the calcium phosphate-gel elution step in earlier methods (Levin et al., 1960; Friedman \& Kaufman, 1965 ) is avoided, yet the same or greater overall purification is achieved, as shown by specific activities. The purity of the final product is demonstrated by using three independent methods; polyacrylamide-gel electrophoresis, sedimentation-velocity ultracentrifugation and rate zonal ultracentrifugation on a sucrose density gradient.

A report has been published (Mylroie \& Koenig, 1971) stating that the soluble proteins of the chromaffin granules are lipoproteins. However, t.l.c. of a chloroform-methanol extract of the active enzyme at the stage after Sephadex G-200 reveals only traces of a cholesterol ester, a triglyceride and possibly a fatty acid. The total lipid content is only approx. $2 \mu \mathrm{g} / \mathrm{mg}$ of protein, hence the isolated enzyme is not a lipoprotein. Further, the presence of lipid is not a prerequisite for enzymic activity in vitro, even if in vivo the enzyme protein is associated with a lipid moiety.

The two preparations of dopamine $\beta$-hydroxylase, obtained by 'hypotonic lysis' or 'Triton lysis', are

Table 2. Release of enzymic activity, total protein and catecholamines from isolated chromaffin granules by various substances

The percentage increases of enzyme, protein and catecholamines in the supernatants after incubation of the granules in vitro over the basal value are given in the presence of various additions. The basal value is taken as the amount released by $\mathrm{NaCl}-\mathrm{KCl}-\mathrm{TES}$ buffer (Poisner \& Trifaro, 1967) in the absence of additives. All additions were at a final concentration of $5 \mathrm{~mm}$ except for ATP $(0.5 \mathrm{~mm})$ and $p$-chloromercuribenzoate $(0.1 \mathrm{mM})$.

Increase (\%)

\begin{tabular}{lccc}
\cline { 2 - 3 } \multicolumn{1}{c}{ Additions } & Activity & Protein & Catecholamines \\
$\mathrm{Mg}^{2+}$ & 13.3 & 0 & 0 \\
$\mathrm{Ca}^{2+}$ & 13.3 & 4.7 & 9.0 \\
ATP & 13.3 & 4.7 & 10.7 \\
$p$-Chloromercuri- & 0 & 0 & 0 \\
benzoate & & & \\
$\mathrm{Mg}^{2+}+\mathrm{Ca}^{2+}$ & 0 & 3.7 & 3.6 \\
$\mathrm{Mg}^{2+}+\mathrm{ATP}$ & 40.0 & 15.9 & 25.0 \\
$\mathrm{Ca}^{2+}+\mathrm{ATP}$ & 82.2 & 0 & 0 \\
$\mathrm{Mg}^{2+}+\mathrm{Ca}^{2+}+\mathrm{ATP}$ & 42.2 & 15.0 & 10.7
\end{tabular}

Vol. 126 


\section{Table 3. Endogenous inhibitor in chromaffin granules}

The crude inhibitor was prepared as described in the Experimental section, and its activity was assayed in the presence and absence of $0.1 \mathrm{mM}$ - $p$-chloromercuribenzoate and $100 \mu \mathrm{M}$ - and $10 \mu \mathrm{M}-\mathrm{CuSO}_{4}$ in the preincubation mixture.

$\begin{array}{lc} & \begin{array}{c}\text { Inhibition } \\ (\%)\end{array} \\ \text { Enzyme control } & 0 \\ \text { Enzyme +inhibitor } & 98.0 \\ \text { Enzyme }+p \text {-chloromercuribenzoate } & 15.5 \\ \text { Enzyme +inhibitor }+p \text {-chloromercuri- } & 97.2 \\ \quad \text { benzoate } & 0 \\ \text { Enzyme }+10 \mu \mathrm{M}-\mathrm{Cu}^{2+} & 97.5 \\ \text { Enzyme }+ \text { inhibitor }+10 \mu \mathrm{M}-\mathrm{Cu}^{2+} & 76.2 \\ \text { Enzyme }+100 \mu \mathrm{M}-\mathrm{Cu}^{2+} & 100 \\ \text { Enzyme }+ \text { inhibitor }+100 \mu \mathrm{M}-\mathrm{Cu}^{2+} & 100 \\ \text { Enzyme }+ \text { inhibitor }+p \text {-chloromercuri- } & \\ \quad \text { benzoate }+100 \mu \mathrm{M}-\mathrm{Cu}^{2+} & \end{array}$

similar in their size parameters, as shown by molecular weight and gel-elution behaviour, and in their total charge as indicated by ion-exchange chromatography at pH7.2 and by polyacrylamide-gel electrophoresis. In addition, the amino acid composition of the two forms of the enzyme was found to be similar. These similarities lead us to suggest that the differences in vivo between the membrane-bound and membraneenclosed enzyme are simply due to a $\mathrm{pH}$ or ionicstrength effect inside the granules, or, more probably, to a specific membrane-adsorption effect. Such an effect has been reported with other enzymes, and has in fact been claimed to be an important control mechanism in the regulation of aldolase activity (Masters et al., 1969).

The results in Table 2 confirm the findings (Poisner \& Trifaro, 1967) that a combination of $\mathrm{Mg}^{2+}$ and ATP is most effective in the release of total protein and catecholamines from chromaffin-granule preparations in vitro. However, the results suggest that $\mathrm{Ca}^{2+}$ alone or in the presence of ATP is more effective for the release of dopamine $\beta$-hydroxylase but not for the other 'soluble' chromaffin-granule proteins. $\mathrm{Ca}^{2+}$ is known to be involved in the release of protein from the granules in vivo, and has been claimed to effect release of protein and of catecholamines in some systems in vitro as well (Oka et al., 1956; Philippu \& Schumann, 1962; Rubin, 1970). The small increments of protein, catecholamine and enzyme activity over basal values, when compared with the increments obtained by other workers in different systems in vitro, could reflect an altered osmotic state of the granules, associated with altered permeability properties, conceivably arising out of this method of isolation of the granules.
It is evident from Table 3 that the boiled lysate of chromaffin granules does contain an endogenous inhibitor of dopamine $\beta$-hydroxylase. This inhibitor appears stable to heating at $100^{\circ} \mathrm{C}$, and to be nonprotein in nature. Further, since it remains in the supernatant after removal of the protein, it is probably soluble within the granules, or only loosely bound to any granular protein in vivo. The inhibition does not appear to be reversed by $p$-chloromercuribenzoate, and hence the inhibitor is probably not a thiol compound, unlike the inhibitor postulated in the soluble fraction of adrenal medullae by Belpaire \& Laduron (1970) and Duch et al. (1968). Further evidence comes from the fact that the isolation procedure used for this crude inhibitor would inactivate any thiol compounds present in the tissue. Since copper also had no reversing effect on the inhibition, we must conclude that the chromaffin-granule inhibitor is also different from the endogenous inhibitor isolated from heart tissue in this laboratory. Further experiments should confirm or deny the presence of these various inhibitors of the enzyme, and shed some light on the physiological significance of this array of naturally occurring inhibitors as regulators in vivo of noradrenaline biosynthesis.

The help of Mr. I. W. Chubb in the early stages of this work is gratefully acknowledged. The work was supported by a grant from the National Heart Foundation of Australia. Thanks are also due to Mr. B. Veitch for the electron microscopy.

\section{References}

Austin, L., Livett, B. G. \& Chubb, I. W. (1967) Circ. Res. 20 and 21, Suppl. 3, 111-117

Belpaire, F. \& Laduron, P. (1968) Biochem. Pharmacol. $17,411-421$

Belpaire, F. \& Laduron, P. (1970) Biochem. Pharmacol. 19, 1323-1331

Cain, D. F. \& Pitney, R. E. (1968) Anal. Biochem. 22, 11-20

Chubb, I. W., Preston, B. N. \& Austin, L. (1969) Biochem. J. 111, 243-244

Creveling, C., Daly, J., Witkop, B. \& Udenfriend, S. (1962) Biochim. Biophys. Acta 64, 125-134

Crout, J. (1961) Stand. Methods Clin. Chem. 3, 62

Duch, D., Viveros, O. \& Kirshner, N. (1968) Biochem. Pharmacol. 17, 255-264

Felsenfeld, G. (1960) Arch. Biochem. Biophys. 87, 247-251

Friedman, S. \& Kaufman, S. (1965) J. Biol. Chem. 240, 4763-4773

Gibb, S., Spector, G. \& Udenfriend, S. (1967) $\mathrm{Mol}$. Pharmacol. 3, 473-478

Goldstein, M., Lauber, E. \& McKereghan, M. R. (1965) J. Biol. Chem. 240, 2066-2072

Kirshner, N. (1962) J. Biol. Chem. 237, 2311-2317

Levin, E. Y., Levenberg, B. \& Kaufman, S. (1960) J. Biol. Chem. 235, 2080-2086

Lowry, O. H., Rosebrough, N. J., Farr, A. L. \& Randall, R. J. (1951) J. Biol. Chem. 193, 265-275 
Martin, R. G. \& Ames, B. N. (1961) J. Biol. Chem. 236, 1372-1379

Masters, C. J., Sheedy, P. J., Winzor, D. J. \& Nichol, L. W. (1969) Biochem. J. 112, 806-808

Mylroie, R. \& Koenig, H. (1971) FEBS Lett. 12, 121124

Oka, M., Okuchi, T., Yoshida, H. \& Imaizumi, R. (1956) Jap. J. Pharmacol. 15, 348-356

Philippu, A. \& Schumann, H. J. (1962) Experientia 18, 138-140

Poisner, A. M. \& Trifaro, J. M. (1967) Mol. Pharmacol. 3, 561-571

Rubin, R. P. (1970) Pharmacol. Rev. 22, 389-428
Smith, A. D. \& Winkler, H. (1967) Biochem. J. 103, 480-482

Smith, W. J. \& Kirshner, N. (1967) Mol. Pharmacol. 3, 52-62

Viveros, O., Arqueros, L. \& Kirshner, N. (1968) Life Sci. 7, 609-618

Viveros, O., Arqueros, L., Connett, R. J. \& Kirshner, N. (1969a) Mol. Pharmacol. 5, 60-68

Viveros, O., Arqueros, L. \& Kirshner, N. (1969b) Mol. Pharmacol. 5, 342-349

Winkler, H., Hortnagl, H., Hortnagl, H. \& Smith, A. D. (1970) Biochem. J. 118, 303-310

Yphantis, D. A. (1964) Biochemistry 3, 297-317 